\title{
CONTINUITY OR A CHANGE OF MEMORY? \\ A BOOK ON THE HISTORICAL POLICIES \\ OF THE LATER POLISH PEOPLE'S REPUBLIC
}

\section{FLORIAN PETERS, REVOLUTION DER ERINNERUNG:}

\section{DER ZWEITE WELTKRIEG IN DER GESCHICHTSKULTUR DES SPÄTSOZIALISTISCHEN POLEN}

\author{
Magdalena Saryusz-Wolska \\ University of Lodz \\ Deutsches Historisches Institut Warschau
}

I read large parts of Florian Peters's book Revolution der Erinnerung: Der Zweite Weltkrieg in der Geschichtskultur des spätsozialistischen Polen [A Revolution of Memory: The Second World War in the Historical Culture of Late-Socialist Poland] on my way back from the Museum of the Second World War in Gdańsk. At the time, the country was in the midst of controversies about the exhibition itself and the dismissal of the director by the right-wing Polish government. The history of the Second World War and its subsequent commemoration were thus topical. The continuities and similarities of the government's current historical policy with the politics of memory in the 1970s and 1980s, as presented by Peters, are striking. Has a "revolution of memory," as the book's title suggests, really taken place since then?

Until recently, the activity of the Solidarity movement, which is one of Peters's central topics, was described primarily in terms of its demands concerning economics, politics, and human rights. This, however, was only a part of the movement's agenda. Peters proves that the majority of publications in the dissident press referred to historical issues (2016: 137). Nevertheless, the memory policies of Solidarity and other opposition groups in 
late-socialist Poland were neglected in academic research of the 1990s and early 2000s. Only during recent years has the topic attracted more interest, stimulated among other things by conflicts of memory that are often provoked by social actors who began their political careers in the underground opposition of the 1970s and 1980s. In his book, Peters offers a detailed overview of both official and opposition memory politics in late-socialist Poland, thus providing a better understanding of the current debates.

Peters has written an extremely comprehensive work, consisting of three introductory chapters, four case studies, and a conclusion. Each of the case studies deserves a separate research project. Peters focuses on latesocialist Polish memory of the Second World War; hence the case studies refer to commemoration of the occupation, the Katyn massacre, the Warsaw Uprising, and the Holocaust. Memories of these events are interwoven. Remembrance of the Katyn massacre is thus connected with remembrance of the Soviet occupation; commemorations of the Warsaw Uprising and the German occupation cannot be analysed separately. As a result, Peters's narrative is extremely dense and detailed, which makes some parts of the book difficult to read. Since Polish collective memory in the 1970s and 1980s was dominated by issues concerning the war, the book covers almost the entire mnemonic discourse of this time.

Peters often uses the language of his sources, thereby helping us to dive into the historical period under examination while also preventing us from maintaining an analytical distance. The keywords in his book are "heroism," "martyrdom," "victims," and "nation." The notions derive from the debates conducted in the 1970s and 1980s, and serve as analytical categories. Peters's theoretical framework also makes reference to contemporary concepts of historical culture (Geschichtskultur) and memory/history politics (Erinnerungs- and Geschichtspolitik). In order to depict the Polish attitude to history in the last two decades of communism, he uses terms that were introduced by German intellectuals such as Jörn Rüsen, Edgar Wolfrum, and Christoph Cornelißen.

Peters identifies four social agents: the state (represented primarily by the notables of the Polish United Workers' Party), the dissidents, the Church, and professional historians. Each was split into smaller groups and often riven by conflicts, which are described by Peters in detail. It is worth mentioning that an insight into the heated debates on Polish memory that were conducted back then can be very useful for discussion of the present situation. The main actors of this discourse, such as Adam Michnik, Marcin Król, Antoni Macierewicz, Lech Wałęsa, and Władysław Bartoszewski, 
have been shaping the Polish public discourse for over forty years - first as members of the Workers' Defence Committee or Solidarity and later in the political debates about the Third Republic (after 1989).

Peters's objects of study include anniversaries - the thirtieth anniversary of the outbreak of the Second World War, the thirty-fifth anniversary of the Warsaw Uprising, the fortieth anniversary of the Katyn massacre, and so on; monuments - the most prominent being the monument of the Warsaw Uprising erected in 1989; press articles, such as the famous essay of 1981, “Two Fatherlands, Two Patriotisms” by Jan Józef Lipski; speeches; and programme papers. His analysis proves that there are only subtle distinctions between history and counter-history. Not only can counter-history become the mainstream narrative after a "revolution," but they are also intertwined. Both the Polish United Workers' Party and the opposition constructed their historical narratives on the basis of notions such as heroism, martyrdom, victimhood, and the nation. Peters analyses these similarities very convincingly. Especially in his last chapter about the memory of the Holocaust he proves that both groups avoided issues relating to the persecution and murder of Jews during the Second World War. During socialism, Poland's collective memory became more and more nationalised and Jews were excluded from the mnemonic community. The German and Soviet occupation was remembered as if it had only been a part of Polish history, even though other ethnic groups, including some 3 million Jews, lived in Poland before the outbreak of the war. When Willy Brandt knelt in front of the Ghetto Monument in Warsaw in 1970 the dominant interpretation in Poland was that his gesture was addressed to Poles. When the Polish television broadcast fragments of Claude Lanzmann's Shoab in the mid-1980s, the Polish audience was interested solely in what the film had to say about Poles, not about the Jews. Although Peters does not focus on the mechanisms of excluding the Jews from Polish collective memory he keeps emphasising that the official and oppositional mnemonic practices were nationalist in kind.

In his last chapter, Peters explains the title of his monograph. As he sees it, the revolution of memory, which among other matters enabled the narratives of marginalised groups (i.e., the Jews) to enter Polish mnemonic practices, was possible because of the preceding social revolution deriving from the Workers' Defence Committee and the Solidarity movement. However, in contrast to the social and - to some extent, political - revolution of the 1970s and 1980s, the mnemonic revolution was limited to the opposition intellectual elites, who supported a broader and more pluralistic 
historical discourse. From the contemporary perspective, this "revolution" has not lasted for more than one generation - if it has really taken place. Most of the Polish elites persist in promoting an ethno-nationalistic view of collective memory. Pluralistic and inclusive narratives remain an exception. Peters explains the roots of these processes very elaborately in his book.

Bibliography:

/// Peters F. 2016. Revolution der Erinnerung: Der Zweite Weltkrieg in der Geschichtskultur des spätsozialistischen Polen, Ch. Links Verlag.

/// Magdalena Saryusz-Wolska - assistant professor at the University of Lódź (Poland) and a researcher at the German Historical Institute, Warsaw. Her research concerns cultural memories and visual cultures in Germany and Poland; her publications in this field include contributions to Participations: Journal Audience \& Reception Studies, German Life and Letters, and Osteuropa.

Email: saryusz-wolska@dhi.waw.pl 